\title{
Molecular Dynamics Study on the Leaching of Zinc-Bearing Dust Sludge by Choline Chloride-Malonic Acid
}

\author{
Jinxia Zhang ${ }^{1,2}$, Chao Yang ${ }^{1}$, Fusheng Niu ${ }^{1,2, *}$, Shuling Gao ${ }^{3}\left[\right.$ and Jiajing Dong ${ }^{1}(\mathbb{D}$ \\ 1 College of Mining Engineering, North China University of Science and Technology, Tangshan 063210, China; \\ kyky@ncst.edu.cn (J.Z.); yc17367534003@stu.ncst.edu.cn (C.Y.); dongjiajing@stu.ncst.edu.cn (J.D.) \\ 2 Hebei Key Laboratory of Mining Development and Safety Technology, Tangshan 063009, China \\ 3 College of Resources and Civil Engineering, Northeastern University, Shenyang 110819, China; \\ gaoshuling@mail.neu.edu.cn \\ * Correspondence: niufusheng@ncst.edu.cn; Tel.: +86-1823-2585-555
}

check for

updates

Citation: Zhang, J.; Yang, C.; Niu, F.; Gao, S.; Dong, J. Molecular Dynamics Study on the Leaching of Zinc-

Bearing Dust Sludge by Choline Chloride-Malonic Acid. Minerals 2021, 11, 1080. https://doi.org/10.3390/ $\min 11101080$

Academic Editors: Jean-François Blais, Siyuan Yang, Yangge Zhu, Cheng Liu and Yanhong Wang

Received: 19 August 2021

Accepted: 25 September 2021

Published: 30 September 2021

Publisher's Note: MDPI stays neutral with regard to jurisdictional claims in published maps and institutional affiliations.

Copyright: (c) 2021 by the authors. Licensee MDPI, Basel, Switzerland. This article is an open access article distributed under the terms and conditions of the Creative Commons Attribution (CC BY) license (https:/ / creativecommons.org/licenses/by/ $4.0 /)$.

\begin{abstract}
Molecular dynamics of the interaction between four metal oxides $\left(\mathrm{ZnO}, \mathrm{Fe}_{2} \mathrm{O}_{3}, \mathrm{Al}_{2} \mathrm{O}_{3}\right.$, and $\mathrm{CaO})$ present in zinc-bearing dust sludge and choline chloride $(\mathrm{ChCl})$-malonic acid (MA)(1:2) was studied in this work using Materials Studio software. The interaction mechanism was revealed by analyzing the interaction energy and radial distribution function from the perspective of quantum mechanics, and the simulation results were verified by single factor leaching experiments. The calculation results show that the complete cleavage surface of the four metal oxides is the (001) surface, and $\mathrm{ChCl}-2 \mathrm{MA}$ forms a stable structure with multiple intermolecular hydrogen bonds centered on the chlorine atom. The dynamic simulation of the interaction model shows that strength of interaction between $\mathrm{ChCl}-2 \mathrm{MA}$ and the four metal oxides follows the order: $\mathrm{ZnO}>\mathrm{Fe}_{2} \mathrm{O}_{3}>\mathrm{Al}_{2} \mathrm{O}_{3}>\mathrm{CaO}$. $\mathrm{ChCl}$-2MA mainly interacts with $\mathrm{ZnO}$ by chemical adsorption, while $\mathrm{ChCl}-2 \mathrm{MA}$ mainly interacts with $\mathrm{Fe}_{2} \mathrm{O}_{3}, \mathrm{Al}_{2} \mathrm{O}_{3}$, and $\mathrm{CaO}$ by physical adsorption. The radial distribution function shows that $\mathrm{Cl}$ in $\mathrm{ChCl}-2 \mathrm{MA}$ and $\mathrm{C}=\mathrm{O}$ in $\mathrm{MA}$ form chemical bonds with $\mathrm{Zn}$ in $\mathrm{ZnO}$, and the choline cation $\left(\mathrm{Ch}^{+}\right)$forms $\mathrm{C}-\mathrm{H} \cdots \mathrm{O}$ with $\mathrm{ZnO}$. Among these bonds, the $\mathrm{Cl}-\mathrm{Zn}$ bond energy is stronger. During the interaction between $\mathrm{ChCl}-2 \mathrm{MA}$ and $\mathrm{Fe}_{2} \mathrm{O}_{3}$ and $\mathrm{Al}_{2} \mathrm{O}_{3}, \mathrm{O}-\mathrm{H} \cdots \mathrm{O}$ and $\mathrm{C}-\mathrm{H} \cdots \mathrm{O}$ are formed and interact with $\mathrm{CaO}$ by van der Waals force. Single factor leaching experiments show that, under the same leaching conditions, the leaching rate of $\mathrm{ZnO}$ by $\mathrm{ChCl}-2 \mathrm{MA}$ is greater than $90 \%$, while the leaching rate of $\mathrm{Fe}_{2} \mathrm{O}_{3}, \mathrm{Al}_{2} \mathrm{O}_{3}$, and $\mathrm{CaO}$ is about $10 \%$. These results indicate good selectivity of ChCl-2MA for $\mathrm{ZnO}$ in the zinc-bearing dust sludge. The above conclusions have important theoretical significance and provide an in-depth understanding of the leaching mechanisms of zinc-bearing dust sludge in deep eutectic solvents.
\end{abstract}

Keywords: zinc-bearing dust sludge; choline chloride-malonic acid; molecular dynamics; interaction energy; radial distribution; selective leaching

\section{Introduction}

Zinc is an important strategic base material, which is often used in alloy production, medical industry, chemical industry, high-tech applications, and certain other fields. Due to the growing demand for zinc resources, high-grade, easily mineable, and easy flotationcontaining zinc mineral resources are depleting. As a result, there is an imbalance between the demand and supply of zinc metal that causes serious obstacles to social progress [1]. Meanwhile, with the rapid economic development and social progress, the demand for crude steel has increased significantly, and a large amount of zinc-bearing dust sludge is produced in the production of crude steel [2]. Zinc-bearing dust sludge is a complex solid waste, which mainly consists of metal oxides, such as $\mathrm{Fe}_{2} \mathrm{O}_{3}, \mathrm{ZnO}, \mathrm{Al}_{2} \mathrm{O}_{3}, \mathrm{CaO}, \mathrm{MgO}$, $\mathrm{Fe}_{3} \mathrm{O}_{4}$, and $\mathrm{CaCO}_{3}[3]$. In terms of the content, the production of zinc-bearing dust sludge is only about $10-12 \%$ of the total output of crude steel. However, the accumulation of excessive raw materials caused by insufficient recovery and utilization of zinc-bearing dust 
sludge has caused serious concerns about the health of ecosystems and humans [4,5]. At present, zinc recovery from zinc-bearing dust sludge is becoming an important pathway to obtain zinc resources [6]. However, there are some drawbacks in the traditional treatment of zinc-bearing dust sludge. For example, the acid leaching treatment in the wet treatment process consumes a large amount of acid. Moreover, iron can easily enter the leaching solution and lead to further complexities to remove iron from the leaching solution $[7,8]$. The ammonia leaching process has the problem of poor dissolution of zinc ferrite, which results in various challenges such as low leaching rate and high ammonia volatility $[9,10]$. In recent years, deep eutectic solvents have been introduced as novel solvents in the field of wet zinc extraction technology. These solvents can be used to leach zinc-bearing dust sludge and are gradually replacing the traditional acid leaching and ammonia leaching processes.

Deep eutectic solvents (DESs) are eutectic mixtures composed of hydrogen-bond donors and hydrogen-bond acceptors, which result in a liquid at room temperature when mixed in a certain molar ratio [11]. As novel green solvents, DESs have attracted extensive attention from researchers all over the world due to various advantages, such as biodegradability, low price, $100 \%$ atom utilization during the synthesis process, and good application prospects in many fields including separation processes and chemical reactions [12,13]. Lei [14] used choline chloride-urea (ChCl-urea) as deep eutectic solvent and added $0.1 \mathrm{~mol} / \mathrm{L}$ ammonia triacetic acid to leach up to $87 \%$ of zinc in the zinc-bearing dust sludge. Zhang [15] studied the leaching of $\mathrm{ZnO}$ using $\mathrm{ChCl}$ and oxalic acid and found that more than $90 \% \mathrm{ZnO}$ could be leached at a liquid-to-solid ratio of 10:1, leaching temperature of $50{ }^{\circ} \mathrm{C}$, leaching time of $2 \mathrm{~h}$, and a mixing speed of $300 \mathrm{r} / \mathrm{min}$. Ashraf [16] dissolved the zinc-bearing dust sludge in a deep eutectic solvent of $\mathrm{ChCl}$-urea and extracted a product containing 38\% zinc from the dust under certain conditions. Zhu [17] used ChCl-ureaethylene glycol to recover zinc from $\mathrm{ZnO}$ dust and found that the leaching rate of zinc was about $85.2 \%$ when the pulp concentration, temperature, and stirring speed were $50 \mathrm{~g} / \mathrm{L}$, $80{ }^{\circ} \mathrm{C}$, and $600 \mathrm{r} / \mathrm{min}$, respectively.

Although choline-based deep eutectic solvents have demonstrated good progress in the leaching of zinc-bearing dust sludge, the molecular analysis of the interaction mechanism between the four metal oxides and a 1:2-mixture of choline chloride and malonic acid (ChCl-2MA) has not yet been reported. In this study, the quantum mechanics software Materials Studio ${ }^{\circledR}$ was used to simulate the crystal structure of the metal oxides and the stable configuration of the deep eutectic solvent. Moreover, an interaction model between the deep eutectic solvent and the complete dissociation surface of metal oxides was also proposed. The proposed interaction model of the deep eutectic solvent and the metal oxides was based on molecular dynamics, and the interaction energy and radial distribution were calculated to analyze the interaction mechanism between four metal oxides and $\mathrm{ChCl}-2 \mathrm{MA}$. The accuracy of the molecular simulation results was verified using single factor leaching experiments.

\section{Modeling and Calculations}

\subsection{Composition Analysis of Zinc-Bearing Dust Sludge}

The zinc-bearing dust sludge was taken from a steel plant in Hebei, China. The main oxide components were analyzed using X-ray fluorescence (XRF, Chuang Xiang Yi Qi, Beijing China), and the corresponding results are presented in Table 1. The results show that the zinc-bearing dust sludge contained $48.20 \% \mathrm{Fe}_{2} \mathrm{O}_{3}, 25.32 \% \mathrm{ZnO}, 6.20 \% \mathrm{Al}_{2} \mathrm{O}_{3}$, and $3.95 \% \mathrm{CaO}$. Moreover, $\mathrm{SO}_{3}$ was heated to produce $\mathrm{SO}_{2}$ gas. The oxide content after the conversion of $\mathrm{SO}_{3}$ to volatile $\mathrm{SO}_{2}$ decreased, thus reducing its effect on the leaching of $\mathrm{ZnO}$. Therefore, the four metal oxides $\left(\mathrm{ZnO}, \mathrm{Fe}_{2} \mathrm{O}_{3}, \mathrm{Al}_{2} \mathrm{O}_{3}\right.$, and $\left.\mathrm{CaO}\right)$ and $\mathrm{ChCl}-2 \mathrm{MA}$ were subjected to molecular dynamics simulation, followed by experimental verification of the proposed model. 
Table 1. Chemical composition analysis of zinc-bearing dust sludge (content.\%).

\begin{tabular}{|c|c|c|c|c|c|c|c|c|c|c|}
\hline Element & $\mathrm{Fe}_{2} \mathrm{O}_{3}$ & $\mathrm{ZnO}$ & $\mathrm{Al}_{2} \mathrm{O}_{3}$ & $\mathrm{CaO}$ & $\mathrm{SO}_{3}$ & $\mathrm{SiO}_{2}$ & $\mathrm{MgO}$ & $\mathrm{PbO}$ & $\mathrm{K}_{2} \mathrm{O}$ & $\mathrm{MnO}$ \\
\hline Content \% & 48.20 & 25.32 & 6.20 & 3.95 & 3.47 & 2.93 & 1.95 & 1.06 & 0.74 & 0.26 \\
\hline $\begin{array}{l}\text { Standard } \\
\text { deviation }\end{array}$ & 0.01 & 0.01 & 0.02 & 0.02 & 0.02 & 0.01 & 0.02 & 0.02 & 0.03 & 0.03 \\
\hline
\end{tabular}

\subsection{Modeling of Metal Oxide Structures and their Cleavage}

\subsubsection{Exchange-Correlation Energy Functionals Test}

According to Joint Committee on Powder Diffraction Standards (JCPDS), the $\mathrm{ZnO}$ lattice parameters are $\mathrm{a}=\mathrm{b}=3.2498 \AA$ and $\mathrm{c}=5.2066 \AA$. The $\mathrm{Fe}_{2} \mathrm{O}_{3}$ lattice parameters are $\mathrm{a}=\mathrm{b}=\mathrm{c}=5.42 \AA$ and $\alpha=\beta=\gamma=55.36^{\circ}$. The $\mathrm{Al}_{2} \mathrm{O}_{3}$ lattice parameters are $\mathrm{a}=\mathrm{b}=4.759 \AA$, $\mathrm{c}=12.991 \AA, \alpha=\beta=90^{\circ}$, and $\gamma=120^{\circ}$. The lattice parameters of $\mathrm{CaO}$ are $\mathrm{a}=\mathrm{b}=\mathrm{c}=4.811 \AA$ and $\alpha=\beta=\gamma=90^{\circ}$. The calculations of the four crystal models were conducted under the Castep module using Materials Studio ${ }^{\circledR}$ software (Materials Studio 2019, Accelrys, San Diego, CA, USA) $[18,19]$. The BFGS optimization algorithm was used in the calculations, and the interaction between the real ion and the valence electron was described by the ultrasoft pseudopotential. The accuracy of the calculations was 'Fine'. TS method was used for DFT-D correction. LDA+U method was used to modify its electronic properties [20-22]. The orbital valence electrons were as follows: Fe- $3 \mathrm{~d}^{6} 4 \mathrm{~s}^{2}, \mathrm{Zn}-3 \mathrm{~d}^{10} 4 \mathrm{~s}^{2}, \mathrm{Al}-3 \mathrm{~s}^{2} 3 \mathrm{p}^{1}, \mathrm{Ca}-4 \mathrm{~s}^{2}$, and $\mathrm{O}-2 \mathrm{~s}^{2} 2 \mathrm{p}^{4}$. The standard parameters of convergence were as follows: the energy convergence value was $1.0 \times 10^{-5} \mathrm{eV} /$ atom; the maximum force between the atoms was $0.05 \mathrm{eV} / \AA$; the maximum internal stress was $0.1 \mathrm{GPa}$; the maximum displacement was $0.002 \AA$. By analyzing cell parameters and total energy calculated by different exchange-correlation energy functionals, the optimal exchange energies were obtained, as shown in Table 2. [23]

Table 2. Optimization results of exchange-correlation energy functionals.

\begin{tabular}{|c|c|c|c|c|c|c|}
\hline \multirow{2}{*}{$\begin{array}{l}\text { Metal } \\
\text { Oxide }\end{array}$} & \multirow{2}{*}{$\begin{array}{c}\text { Exchange- } \\
\text { Correlation } \\
\text { Energy } \\
\end{array}$} & \multicolumn{2}{|c|}{ Cell Parameters } & \multicolumn{2}{|c|}{ Error/\% } & \multirow{2}{*}{$\begin{array}{c}\text { Total } \\
\text { Energy/eV }\end{array}$} \\
\hline & & $\mathbf{a}$ & c & $\mathbf{a}$ & c & \\
\hline \multirow{5}{*}{$\mathrm{ZnO}$} & LDA(CA-PZ) & 3.191 & 5.158 & 1.81 & 0.93 & -4300.24 \\
\hline & GGA(PBE) & 3.289 & 5.309 & 1.21 & 1.97 & -4294.54 \\
\hline & GGA(RPBE) & 3.319 & 5.358 & 2.15 & 2.91 & -4296.55 \\
\hline & GGA(PW91) & 3.288 & 5.291 & 1.18 & 1.62 & -4299.28 \\
\hline & GGA(PBEsol) & 3.269 & 5.225 & 0.62 & 0.38 & -4299.26 \\
\hline \multirow{5}{*}{$\mathrm{Fe}_{2} \mathrm{O}_{3}$} & LDA(CA-PZ) & \multicolumn{2}{|c|}{5.319} & \multicolumn{2}{|c|}{1.86} & -6060.58 \\
\hline & GGA(PBE) & \multicolumn{2}{|c|}{5.342} & \multicolumn{2}{|c|}{1.44} & -6079.93 \\
\hline & GGA(RPBE) & \multicolumn{2}{|c|}{5.369} & \multicolumn{2}{|c|}{0.94} & -6089.15 \\
\hline & GGA(PW91) & \multicolumn{2}{|c|}{5.355} & \multicolumn{2}{|c|}{1.19} & -6090.99 \\
\hline & GGA(PBEsol) & \multicolumn{2}{|c|}{5.286} & \multicolumn{2}{|c|}{2.58} & -6046.69 \\
\hline \multirow{5}{*}{$\mathrm{Al}_{2} \mathrm{O}_{3}$} & LDA(CA-PZ) & 4.705 & 12.803 & 1.13 & 1.44 & -2864.36 \\
\hline & GGA(PBE) & 4.787 & 13.1 & 0.58 & 0.83 & -2861.77 \\
\hline & GGA(RPBE) & 4.682 & 12.709 & 0.16 & 2.17 & -2863.81 \\
\hline & GGA(PW91) & 4.784 & 13.083 & 0.52 & 0.7 & -2865.34 \\
\hline & GGA(PBEsol) & 4.783 & 13.001 & 0.5 & 0.07 & -2854.57 \\
\hline \multirow{5}{*}{$\mathrm{CaO}$} & LDA(CA-PZ) & \multicolumn{2}{|c|}{4.732} & \multicolumn{2}{|c|}{1.64} & -1414.49 \\
\hline & GGA(PBE) & \multicolumn{2}{|c|}{4.733} & \multicolumn{2}{|c|}{1.62} & -1441.65 \\
\hline & GGA(RPBE) & \multicolumn{2}{|c|}{4.353} & \multicolumn{2}{|c|}{9.51} & -1442.62 \\
\hline & GGA(PW91) & \multicolumn{2}{|c|}{4.745} & \multicolumn{2}{|c|}{1.37} & -1442.83 \\
\hline & GGA(PBEsol) & \multicolumn{2}{|c|}{4.714} & \multicolumn{2}{|c|}{2.05} & -1438.57 \\
\hline
\end{tabular}

The results presented in Table 2 show the optimized values of different exchangecorrelation energy functionals, which indicate that the total energy of $\mathrm{ZnO}$ was always maintained at about $-4300 \mathrm{eV}$ under various exchange-correlation energy functionals calculations. The cell parameter error calculated by GGA (PBEsol) exchange-correlation energy functional was the smallest among all exchange-correlation energy functionals, and the lattice constant error was within $2 \%$. At the same time, the calculated cell parameters 
of $\mathrm{ZnO}$ were in agreement with experimental reports, so GGA (PBEsol) was selected to calculate the $\mathrm{ZnO}$ crystal cell [24]. The cell parameter error $\mathrm{a}=\mathrm{b}=\mathrm{c}=0.941 \%$ of $\mathrm{Fe}_{2} \mathrm{O}_{3}$ obtained under GGA (RPBE) exchange-correlation energy functional was the smallest error among all exchange-correlation energy functionals values, and the total energy of $-6089.15 \mathrm{eV}$ was not very different from the optimal parameter. Therefore, GGA (RPBE) was selected to calculate the $\mathrm{Fe}_{2} \mathrm{O}_{3}$ crystal cell. The simulation results were in good agreement with the experimental results [25]. GGA (PW91) was selected to calculate the $\mathrm{Al}_{2} \mathrm{O}_{3}$ crystal cell, the results of which were consistent with the experimental results. The parameters of GGA (PBEsol) exchange-correlation energy functional had the smallest error, but the total energy was the largest [26]. The cell parameter error of $\mathrm{CaO}$ calculated by GGA (PW91) was the best parameter among all related energy calculations, and the total energy was not different from $-1414.49 \mathrm{eV}$ calculated by LDA (CA-PZ). Therefore, GGA (PW91) was selected to calculate the $\mathrm{CaO}$ cell. The simulation results were in good agreement with the experimental results [27].

\subsubsection{Complete-Cleavage Surface Calculations}

During the leaching of zinc-bearing dust sludge, the adsorption of the agent mainly occurs on the mineral surface. In the process of crushing, grinding, and other processing steps, minerals are fractured along the surface with weak bonding inside the crystal under the action of external forces, forming a stable surface with low surface energy. That is, the lowest surface energy is the complete-cleavage surface $[28,29]$. For this reason, the surface energy of the common surfaces of the four metal oxides was calculated in the current study to determine the complete cleavage. The smaller the surface energy, the easier it is to become the surface of the mineral-drug [30]. The results presented in Table 3 show the common surface energy values of the four metal oxides.

Table 3. Common surface energies of metal oxides $\left(\mathrm{J} / \mathrm{m}^{2}\right)$.

\begin{tabular}{cccccc}
\hline Metal Oxide & $\mathbf{0 0 1}$ & $\mathbf{0 1 1}$ & $\mathbf{1 1 1}$ & $\mathbf{1 0 1}$ & $\mathbf{1 1 0}$ \\
\hline $\mathrm{ZnO}$ & 0.8177 & 3.9275 & 3.9271 & 2.0852 & 2.4053 \\
$\mathrm{Fe}_{2} \mathrm{O}_{3}$ & 1.9021 & 1.9425 & 1.9326 & - & 1.9308 \\
$\mathrm{Al}_{2} \mathrm{O}_{3}$ & 1.7651 & 2.1034 & - & 1.7942 & 2.1127 \\
$\mathrm{CaO}$ & 1.1723 & 1.5974 & 1.7486 & 1.5813 \\
\hline
\end{tabular}

The surface energy is calculated using Equation (1).

$$
E_{\text {surf }}=\frac{E_{\text {slab }}-\left(\frac{N_{\text {slab }}}{N_{\text {bulk }}}\right) E_{\text {bulk }}}{2 \mathrm{~A}}
$$

where $E_{\text {slab }}$ and $E_{\text {bulk }}$ refer to the total energy of the mineral layer crystal model and the unit cell model, respectively $(\mathrm{eV}), \mathrm{N}_{\text {slab }}$ refers to the total number of atoms in the layer crystal model, $\mathrm{N}_{\text {bulk }}$ is the total number of atoms in the unit cell model, $\mathrm{A}$ is the area of the layer crystal model along the Z-axis $\left(\times 10^{-20} \mathrm{~m}^{2}\right)$, and ' 2 ' accounts for the two surfaces along the Z-axis of the layered crystal model.

The results presented in Table 3 show the surface energy of the common surfaces of the four metal oxides and reveal that the surface energy of $\mathrm{ZnO}(001)$ surface $\mathrm{E}_{\text {surf }}=0.8177 \mathrm{~J} / \mathrm{m}^{2}$ was the smallest among the five surface energies, indicating that the $\mathrm{ZnO}(001)$ surface underwent complete cleavage. The surface energy of $\mathrm{Fe}_{2} \mathrm{O}_{3}(001)\left(\mathrm{E}_{\text {surf }}=1.9021 \mathrm{~J} / \mathrm{m}^{2}\right)$ was the lowest among the common surfaces. Therefore, it was inferred that $\mathrm{Fe}_{2} \mathrm{O}_{3}$ underwent complete cleavage. For the common surfaces of $\mathrm{Al}_{2} \mathrm{O}_{3}(001)$, the surface energy value $\left(\mathrm{E}_{\text {surf }}=1.7651 \mathrm{~J} / \mathrm{m}^{2}\right)$ indicated complete cleavage of $\mathrm{Al}_{2} \mathrm{O}_{3}$. The surface energy of $\mathrm{CaO}$ (001) surface $\left(\mathrm{E}_{\text {surf }}=1.1723 \mathrm{~J} / \mathrm{m}^{2}\right)$ was the lowest among the five surface energies, indicating complete cleavage. The complete-cleavage surfaces of four metal oxides obtained by surface energy calculations were in agreement with the experimental results previously reported, which proves the reliability of the complete-cleavage surfaces obtained by surface energy calculation [31-33]. 


\subsubsection{Density of States Analysis}

Calculating the metal oxide cell and the complete-cleavage surface state density can provide the surface atomic activity size because the physical and chemical reactions always occur near the Fermi level. The closer to the Fermi level, the stronger the electronic activity. The farther the energy level, the lower the energy. In the latter case, the electron does not easily participate in the reaction [34-36]. Figure 1 shows the comparison of the density of states of the four single minerals; the dotted green lines indicate the Fermi energy levels of each metal oxide.

By comparing the density of states of $\mathrm{ZnO}$ cell and complete-cleavage surface, it is found that the peak of the complete cleavage surface increased at the highest occupied state. Moreover, the peak rose, mainly because the O-2p and $\mathrm{Zn}-3 \mathrm{~d}$ contributed to the highest occupied state; the $\mathrm{Zn}-3 \mathrm{~d}$ orbital contributed more than the O-2p orbital. The results also show that the surface $\mathrm{Zn}$ activity of $\mathrm{ZnO}$ (001) was relatively high. By comparing the $\mathrm{Fe}_{2} \mathrm{O}_{3}$ cell and complete-cleavage surface state density, it can be seen that the highest occupied state of the complete-cleavage surface near the Fermi level shifted to the left, while the highest occupied peak area became larger and the peak value increased. This was mainly due to the increase in the peak areas of Fe-3d and O-2p orbitals near the Fermi level, indicating that both $\mathrm{Fe}$ and $\mathrm{O}$ activities in the $\mathrm{Fe}_{2} \mathrm{O}_{3}$ (001) surface increased. By comparing the density of states of the $\mathrm{Al}_{2} \mathrm{O}_{3}$ cell and the complete-cleavage surface, it is found that the peak of the total density of states of the complete-cleavage surface increased, which is mainly due to the increase in the density of state of $\mathrm{O}-2 \mathrm{p}$, indicating that $\mathrm{O}$ in the $\mathrm{Al}_{2} \mathrm{O}_{3}$ (001) surface was more active and reacted more easily with foreign substances than other species. By comparing the density of states of the $\mathrm{CaO}$ cell and the complete-cleavage surface, it can be seen that the peak density of states of the complete-cleavage surface increased, which is mainly because the peaks of $\mathrm{Ca}$ and $\mathrm{O}$ partial-wave density of states increased. The peak of the density of states near the Fermi level was mainly contributed by $\mathrm{O}-2 \mathrm{p}$, indicating that $\mathrm{O}$ was more likely to react with foreign substances in the completecleavage surface of $\mathrm{CaO}$. In short, considering the complete-cleavage surface of the four metal oxides, $\mathrm{Zn}$ was more active than $\mathrm{O}$ in the $\mathrm{ZnO}(001)$ surface, whereas $\mathrm{Fe}$ and $\mathrm{O}$ had similar activities in the $\mathrm{Fe}_{2} \mathrm{O}_{3}$ (001) surface. Moreover, $\mathrm{O}$ in $\mathrm{Al}_{2} \mathrm{O}_{3}$ (001) and $\mathrm{CaO}$ (001) was more active than $\mathrm{Al}$ and $\mathrm{Ca}$.

\subsection{Construction and Calculation of Eutectic Solvent Model}

In the current study, $\mathrm{ChCl}$ was used as the hydrogen bond acceptor, while MA was used as the hydrogen bond donor. Both $\mathrm{ChCl}$ and $\mathrm{MA}$ were used in a 1:2 molar ratio to simulate the ChCl-2MA cluster model. Dmol3 module in Materials Studio was used to build the cluster model. A generalized gradient was used in the construction of the model. In addition, approximation (GGA) and BLYP density functional were used, while the calculation accuracy was 'Fine'. The DNP 4.4 basis set was selected, and the total energy convergence value of the system was $1.0 \times 10^{-5} \mathrm{eV} /$ atom. Moreover, the maximum internal stress was $0.002 \mathrm{Ha} / \AA$, and the maximum displacement was $0.005 \AA$. All-electronic nuclear processing method was selected for the simulation [37]. The phonon spectra of $\mathrm{ChCl}-2 \mathrm{MA}$ and the optimized stable configuration of $\mathrm{ChCl}-2 \mathrm{MA}$ were obtained from the simulation. Figure 2 shows the phonon spectrum of the stable configuration of $\mathrm{ChCl}-2 \mathrm{MA}$ deep eutectic solvent. Furthermore, Figure 3 shows the stable configuration of $\mathrm{ChCl}-2 \mathrm{MA}$ deep eutectic solvent. 


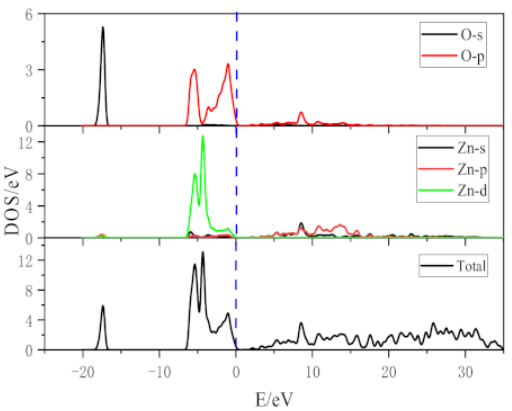

(a)

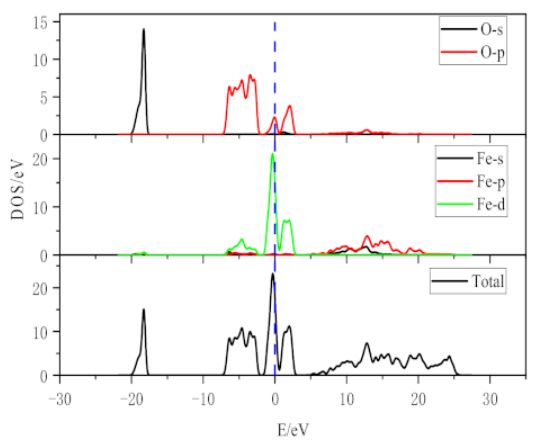

(c)

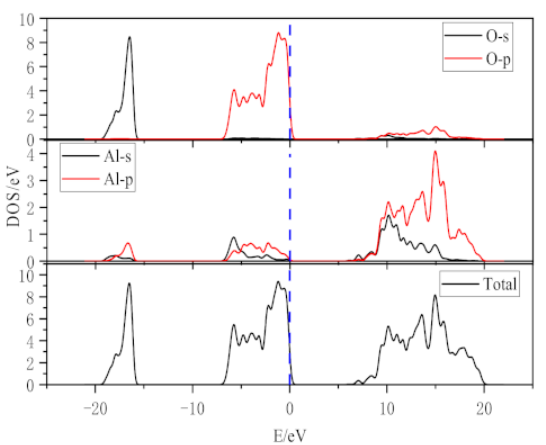

(e)

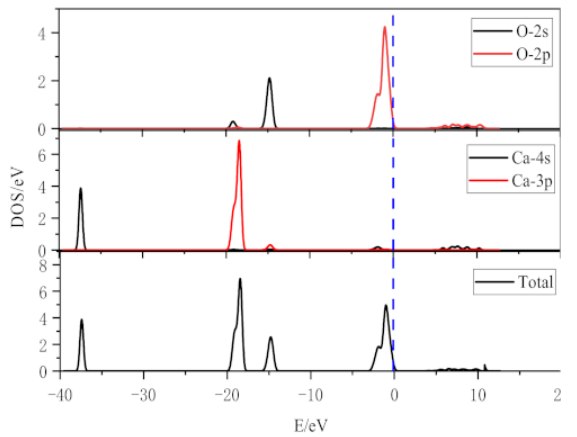

(g)

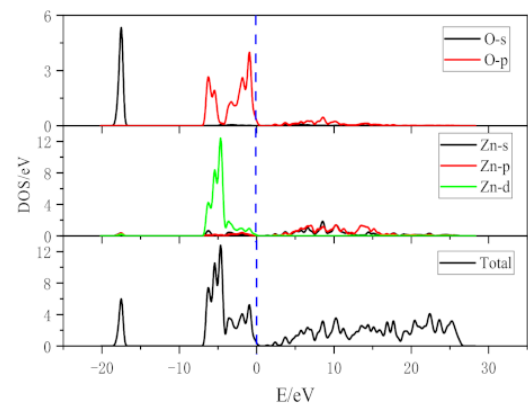

(b)

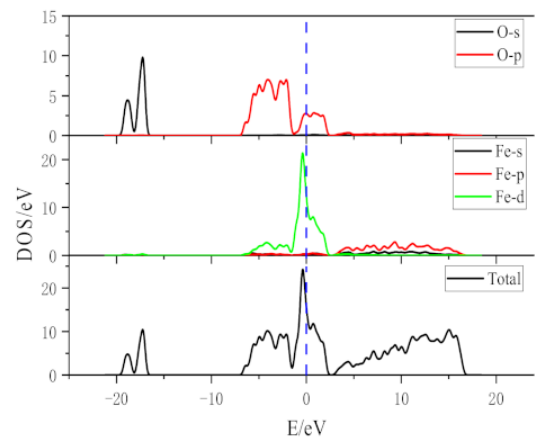

(d)

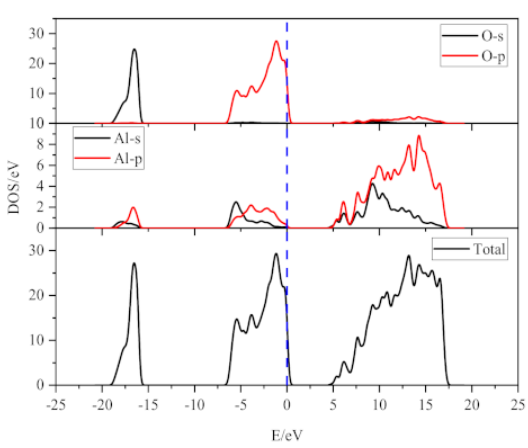

(f)

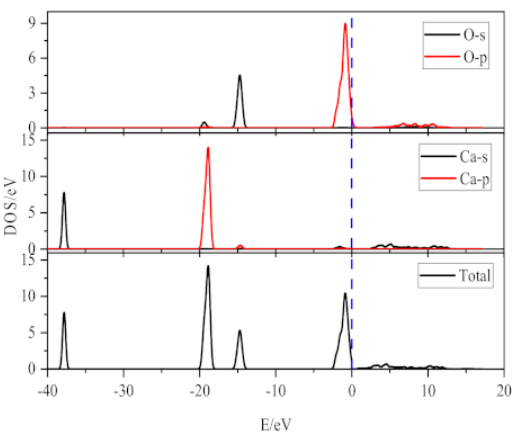

(h)

Figure 1. Density of states contrast diagram of metal oxides. Comparison of $\mathrm{ZnO}$ density of states ((a): $\mathrm{ZnO}$ cell (b): $\mathrm{ZnO}$ (001) surface). Comparison of $\mathrm{Fe}_{2} \mathrm{O}_{3}$ density of states ((c): $\mathrm{Fe}_{2} \mathrm{O}_{3}$ cell (d): $\mathrm{Fe}_{2} \mathrm{O}_{3}$ (001) surface). Comparison of $\mathrm{Al}_{2} \mathrm{O}_{3}$ density of states $\left((\mathbf{e}): \mathrm{Al}_{2} \mathrm{O}_{3}\right.$ cell (f): $\mathrm{Al}_{2} \mathrm{O}_{3}(001)$ surface. Comparison of $\mathrm{CaO}$ density of states $((\mathbf{g}): \mathrm{CaO}$ cell $(\mathbf{h}): \mathrm{CaO}(001)$ surface). 


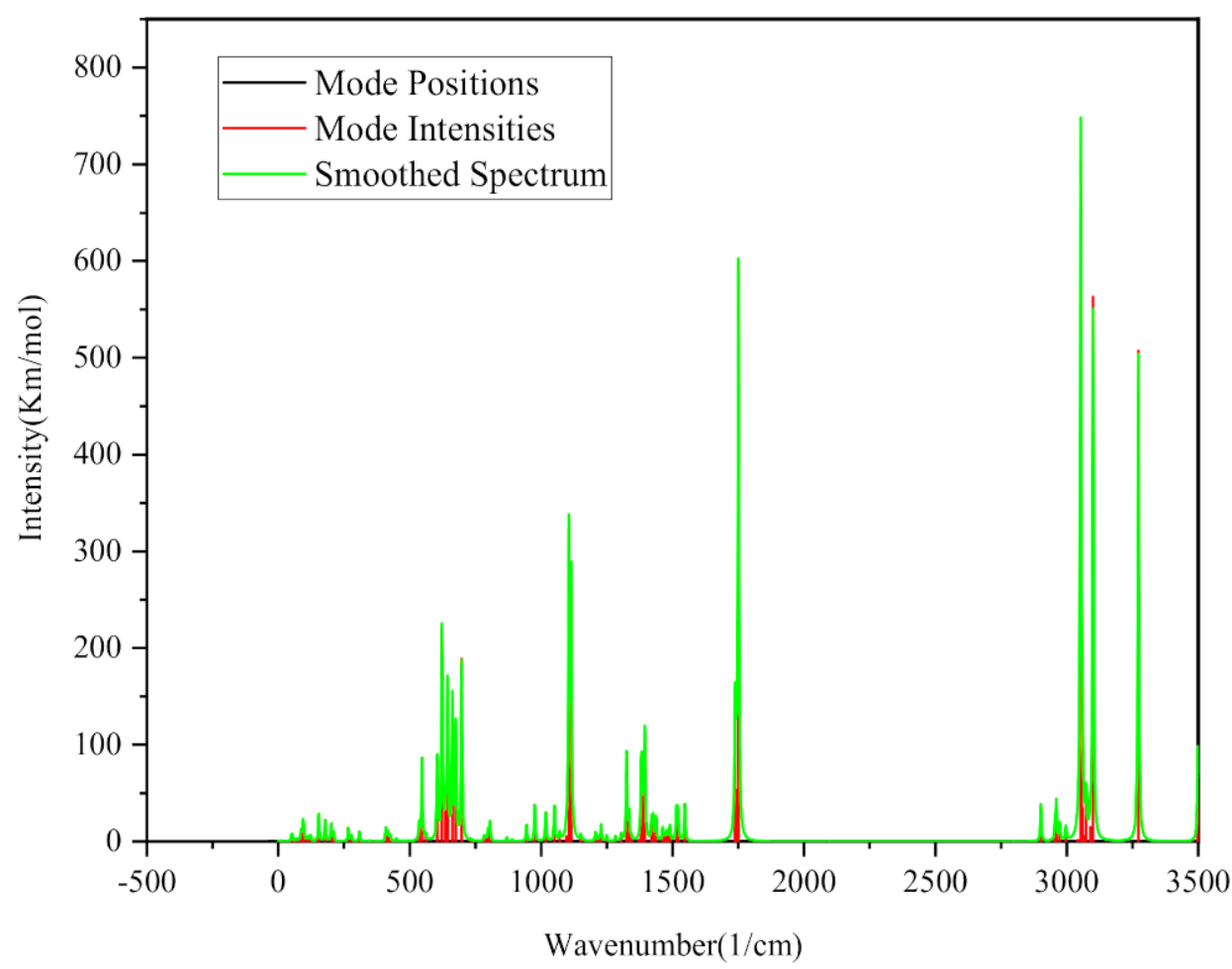

Figure 2. Phonon spectrum of ChCl-2MA deep eutectic solvent.

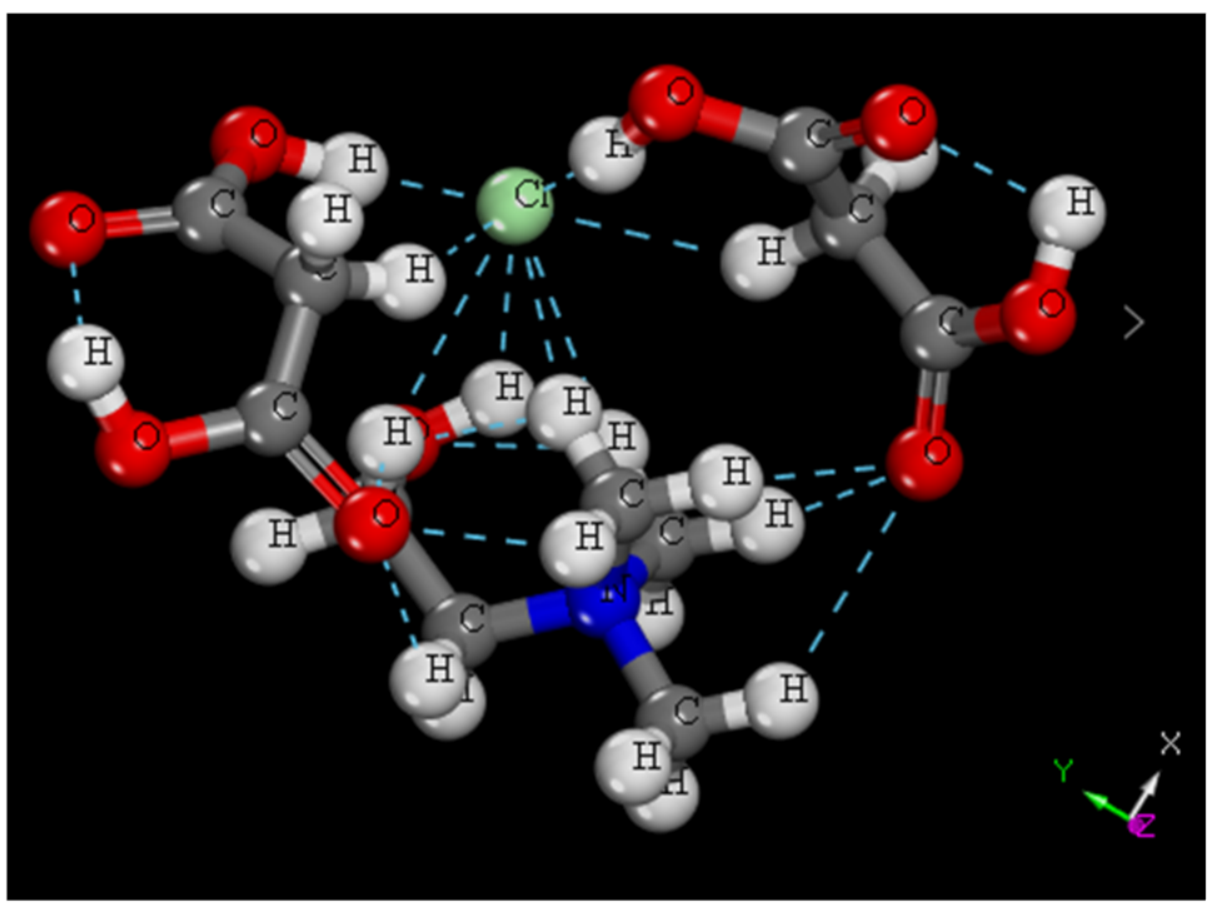

Figure 3. Stable configuration of ChCl-2MA deep eutectic solvent.

As can be seen from Figure 2, in the process of forming the stable configuration of ChCl-2MA deep eutectic solvent, the X-coordinate turned out to be negative, while part of the value was uncountable, indicating that the formed $\mathrm{ChCl}-2 \mathrm{MA}$ deep eutectic solvent had a fixed structure without any virtual frequency. As seen from Figure 3, the stable structure formed by $\mathrm{ChCl}$ and $\mathrm{MA}$ was a multi-molecular hydrogen bond structure 
centered on the chlorine atom, which played a crucial role in the stability of intermolecular hydrogen bonds.

\section{Calculation and Analysis of the Interaction}

\subsection{Construction of the Interaction Model}

The establishment of a stable interaction model is the premise for analyzing the interaction mechanism by $\mathrm{ChCl}$ and $\mathrm{MA}$ on the complete-cleavage surface of the four metal oxides and the basis of molecular dynamics simulation. Therefore, by optimizing the surface model of the complete-cleavage surface of the four metal oxides and the stable $\mathrm{ChCl}$-2MA eutectic solvent model, the 'Build Layer' was used to add the molecular layer of the $\mathrm{ChCl}-2 \mathrm{MA}$ eutectic solvent to the four metal oxides. On the physical surface, a mineraldrug interaction model was established, and a certain vacuum layer was included to reduce the influence of periodic structure. The established interaction model was optimized, and kinetic calculations were carried out with the Forcite module [38,39]. During the calculation, the force field was COMPASSII, and the charge distribution was Forcefield-assigned. Furthermore, the calculation accuracy was set to 'Fine', and the electrostatic potential and van der Waals summing methods were the Ewald- and Atom-based, respectively. Various parameters, such as energy, temperature, and stable interaction model, were calculated using molecular dynamics, and the interaction energy and radial distribution function were calculated using the stable interaction model. Thus, the interaction mechanism between $\mathrm{ChCl}-2 \mathrm{MA}$ and the four metal oxides was studied. Figure 4 shows the variations in energy and temperature in the molecular dynamics simulation of the four metal oxides and $\mathrm{ChCl}$ 2MA. In addition, Figure 5 shows the interaction model of the four metal oxides and that of $\mathrm{ChCl}-2 \mathrm{MA}$, which were obtained using the simulation.

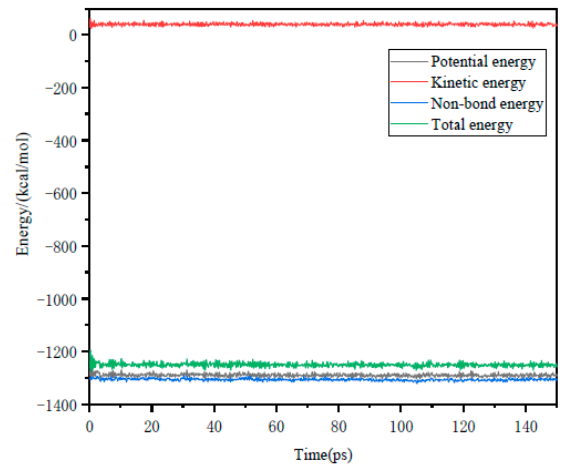

(a)

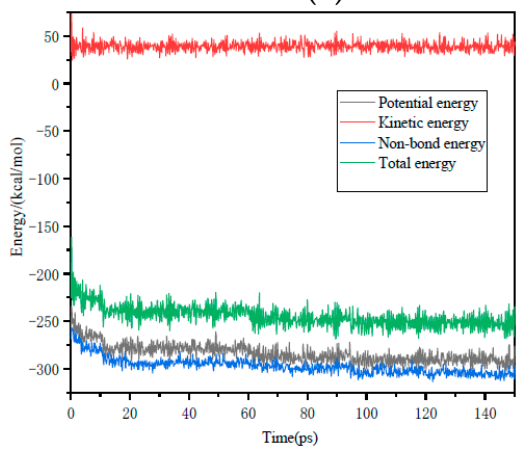

(c)

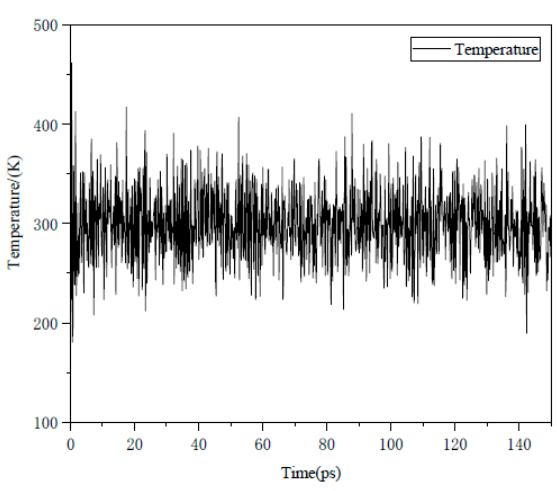

(b)

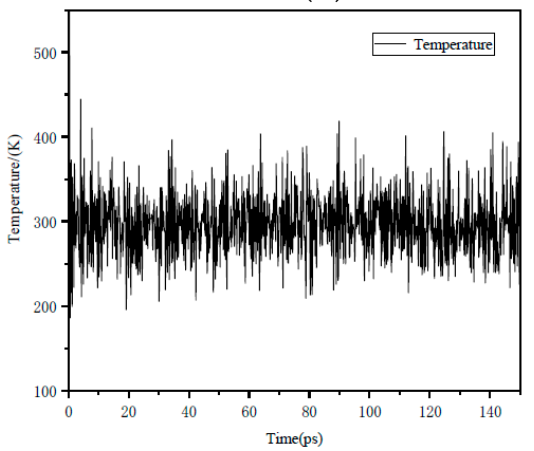

(d)

Figure 4. Cont. 


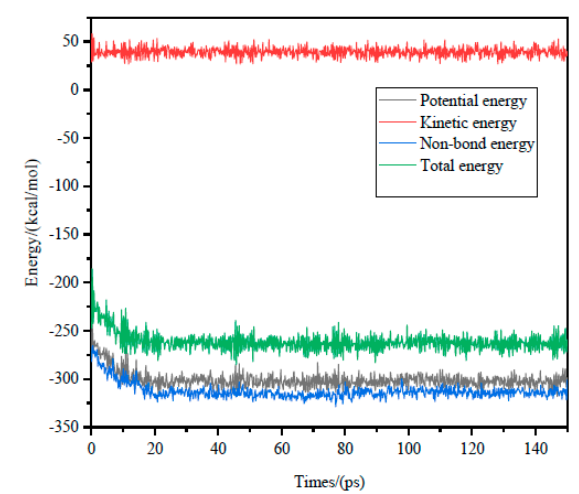

(e)

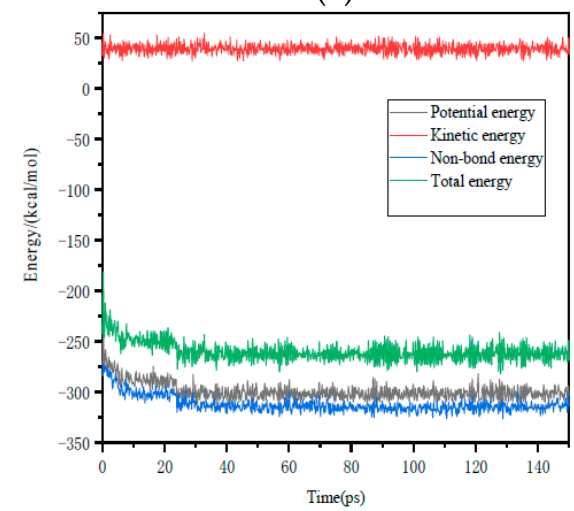

(g)

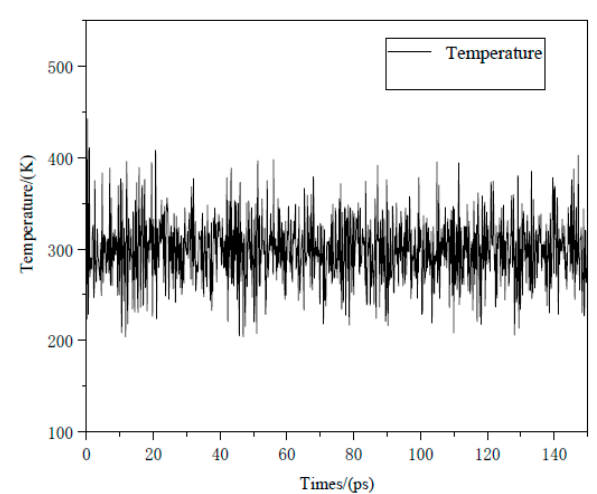

(f)

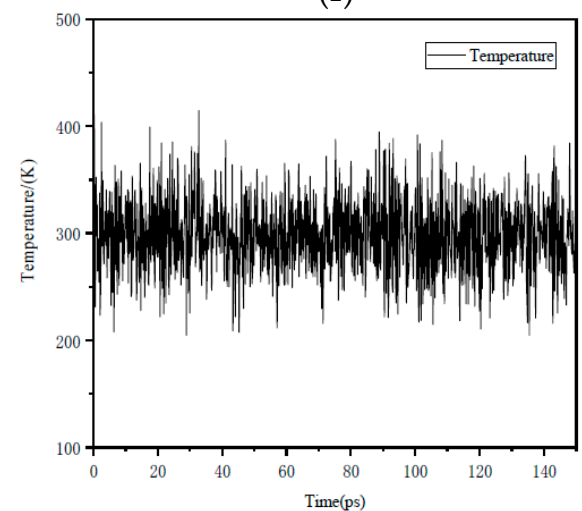

(h)

Figure 4. Molecular dynamics simulation of different metal oxides with ChCl-2MA. Dynamic simulation of ChCl-2MA on $\mathrm{ZnO}$ (001) surface ((a): energy change (b): temperature change). Dynamic simulation of $\mathrm{ChCl}-2 \mathrm{MA}$ on $\mathrm{Fe}_{2} \mathrm{O}_{3}$ (001) surface ((c): energy change (d): temperature change). Dynamic simulation of $\mathrm{ChCl}-2 \mathrm{MA}$ on $\mathrm{Al} 2 \mathrm{O} 3$ (001) surface ((e): energy change (f): temperature change). Dynamic simulation of $\mathrm{ChCl}-2 \mathrm{MA}$ on $\mathrm{CaO}(001)$ surface $((\mathbf{g})$ : energy change $(\mathbf{h})$ : temperature change).

As can be seen from Figure 4, after the NVT ensemble simulation, the energy and temperature continuously changed. Finally, the energy of the interaction process between the four metal oxides and $\mathrm{ChCl}-2 \mathrm{MA}$ stabilized, and the range of the temperature variation was not large, indicating that the simulated system had reached a stable structure. Meanwhile, based upon the variations in energy, the total energy in the interaction process between $\mathrm{ChCl}-2 \mathrm{MA}$ and $\mathrm{ZnO}$ (001) was found to be low, and the total energy of the other three metal oxides was relatively high, which further shows that ChCl-2MA and ZnO (001) were more likely to react.

It can be seen from Figure 5 that the hydrogen bond of $\mathrm{ChCl}-2 \mathrm{MA}$ was broken during the interaction with $\mathrm{ZnO}$ (001), and the reactions took place on the upper and lower surfaces of $\mathrm{ZnO}$ (001). Moreover, $\mathrm{Cl}$ and $\mathrm{O}$ on the two MA molecules acted on the protruding surface of $\mathrm{Zn}$, while choline cation acted on the protruding surface of $\mathrm{O}$ and formed $\mathrm{C}-\mathrm{H} \cdots \mathrm{O}$ hydrogen bonds with it. Meanwhile, $\mathrm{ChCl}-2 \mathrm{MA}$ formed $\mathrm{C}-\mathrm{H} \cdots \mathrm{O}$ and $\mathrm{O}-\mathrm{H} \cdots \mathrm{O}$ hydrogen bonds during the interaction with $\mathrm{Fe}_{2} \mathrm{O}_{3}(001)$ and $\mathrm{Al}_{2} \mathrm{O}_{3}(001)$ surfaces. No hydrogen bond was observed between $\mathrm{ChCl}-2 \mathrm{MA}$ and $\mathrm{CaO}(001)$. 


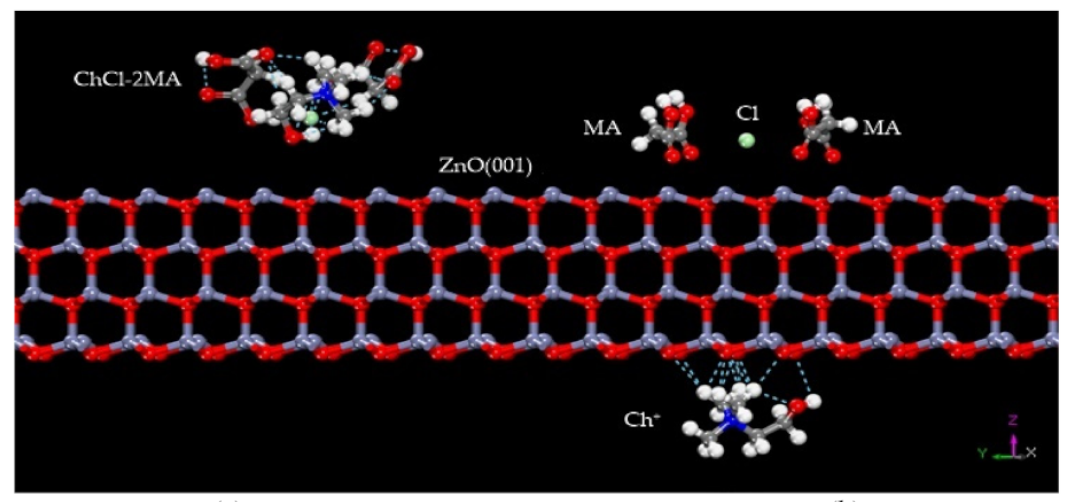

(a)

(b)

$\mathrm{ChCl}-2 \mathrm{MA}$ and $\mathrm{ZnO}$ (001) surface interaction model ((a): interaction before (b): interaction after): $\mathrm{O}$ : red, $\mathrm{H}$ : white, $\mathrm{Zn}$ : gray

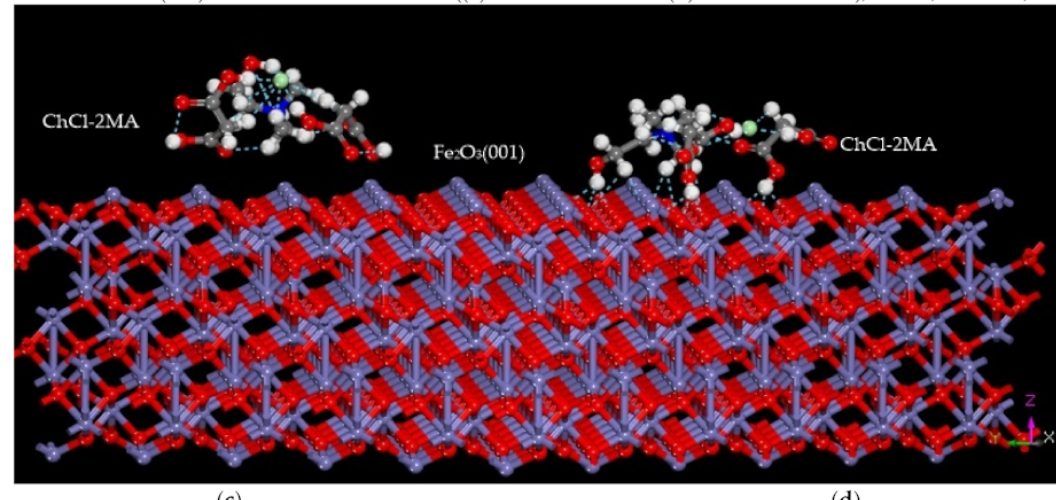

(c)

(d)

ChCl-2MA and $\mathrm{Fe}_{2} \mathrm{O}_{3}$ (001) surface interaction model ((c): interaction before (d): interaction after); O: red, $\mathrm{H}$ : white, Fe: gray

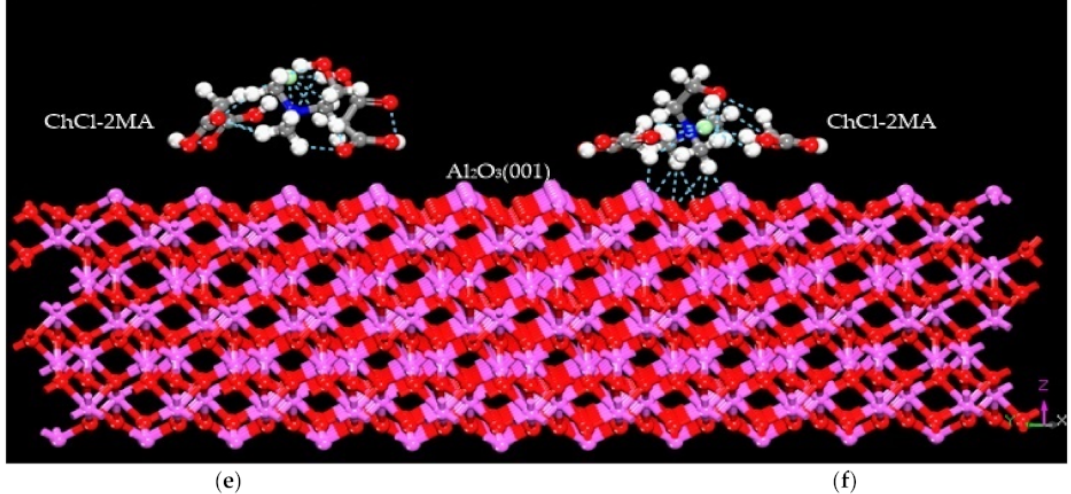

$\mathrm{ChCl}-2 \mathrm{MA}$ and $\mathrm{Al}_{2} \mathrm{O}_{3}(001)$ surface interaction model ((e): interaction before (f): interaction after); $\mathrm{O}$ : red, $\mathrm{H}$ : white, $\mathrm{Al}$ : pink

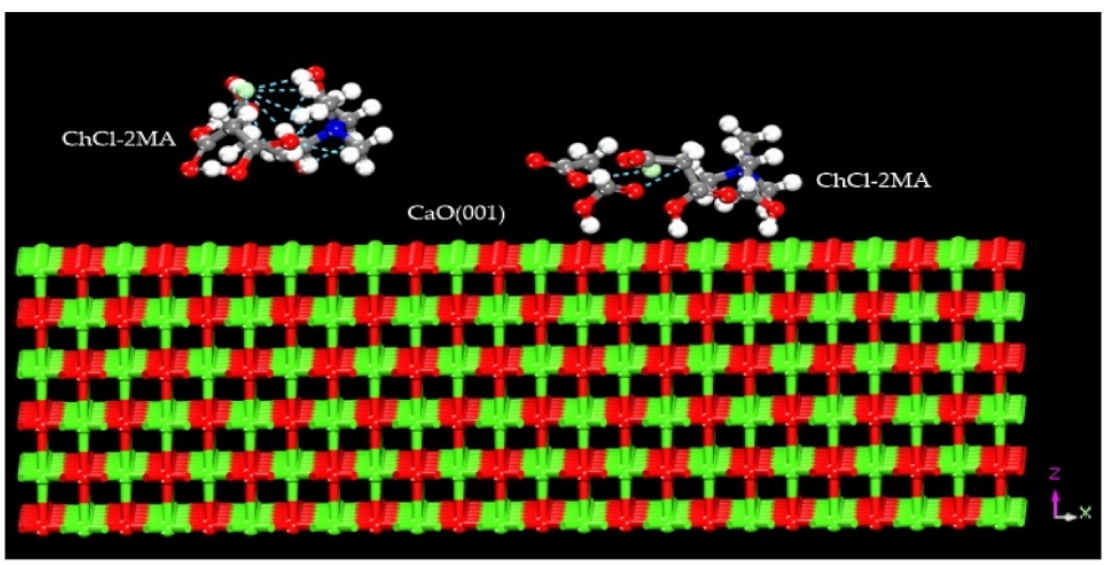

$(\mathrm{g})$

(h)

$\mathrm{ChCl}-2 \mathrm{MA}$ and $\mathrm{CaO}(001)$ surface interaction model ((g): interaction before $(\mathbf{h})$ : interaction after); O: red, $\mathrm{H}$ : white, Ca: green

Figure 5. Interaction models of different metal oxides and $\mathrm{ChCl}-2 \mathrm{MA}$. 


\subsection{Analysis of the Calculated Results \\ 3.2.1. Interaction Energy}

The interaction energy is calculated using the correlation: $\triangle \mathrm{E}=\mathrm{E}_{\mathrm{AB}}-\mathrm{E}_{\mathrm{A}}-\mathrm{E}_{\mathrm{B}}$, where $\triangle E$ is the interaction energy of the eutectic solvent and metal oxide after interaction, and $\mathrm{E}_{\mathrm{AB}}, \mathrm{E}_{\mathrm{A}}$, and $\mathrm{E}_{\mathrm{B}}$ are the total energy of the interaction model, the metal oxide, and the eutectic solvent, respectively. With decreasing interaction energy, the stability of the adsorption increases, and vice versa [40]. The results presented in Table 4 outline the calculated interaction energies between the complete-cleavage surfaces of the four metal oxides and $\mathrm{ChCl}-2 \mathrm{MA}$.

Table 4. Interaction energies between the complete-cleavage surfaces of the metal oxides and ChCl-2MA (/eV).

\begin{tabular}{ccccc}
\hline $\begin{array}{c}\text { Complete-Cleavage } \\
\text { Surface }\end{array}$ & $\mathbf{E}_{\mathbf{A}}$ & $\mathbf{E}_{\mathbf{B}}$ & $\mathbf{E}_{\mathbf{A B}}$ & \multicolumn{1}{c}{$\mathbf{E}$} \\
\hline $\mathrm{ZnO}(001)$ & 6.3368 & $-10,983.7106$ & $-11,015.7309$ & -38.3572 \\
$\mathrm{Fe}_{2} \mathrm{O}_{3}(001)$ & 1.2463 & $-42,885.9960$ & $-42,887.9668$ & -4.1929 \\
$\mathrm{Al}_{2} \mathrm{O}_{3}(001)$ & -9.2960 & $-13,7351.4606$ & $-13,7364.4290$ & -3.6724 \\
$\mathrm{CaO}(001)$ & -10.6916 & -7373.6033 & -7360.4413 & -2.4703 \\
\hline
\end{tabular}

The results presented in Table 4 show that the interaction energy between the $\mathrm{ZnO}$ (001) surface and ChCl-2MA was the smallest $(-38.3572 \mathrm{eV})$, whereas the interaction between the four metal oxides and $\mathrm{ChCl}-2 \mathrm{MA}$ was indeed the strongest. Furthermore, the interaction energies of the three metal oxides and $\mathrm{ChCl}-2 \mathrm{MA}$ were relatively similar to each other, and the strength of the interaction was found to be in the following descending order: $\mathrm{Fe}_{2} \mathrm{O}_{3}(001)$ surface $>\mathrm{Al}_{2} \mathrm{O}_{3}(001)$ surface $>\mathrm{CaO}(001)$ surface.

\subsubsection{Radial Distribution Function}

The radial distribution function (RDF) indicates the spatial distribution probability of other particles centered on a given particle and is used to analyze the strength of the interaction between two substances. The peaks within $3.5 \AA$ mainly indicate the existence of chemical bonds or hydrogen bonding between the substances. The peaks beyond $3.5 \AA$ mainly indicate that the interaction between substances is Coulombic force or van der Waals force [41,42]. Figure 6 shows the atomic radial distribution of four metal oxides during the interaction with $\mathrm{ChCl}-2 \mathrm{MA}$.

The results show that $\mathrm{Cl}$ in $\mathrm{ChCl}$ forms a chemical bond with $\mathrm{Zn}$ in $\mathrm{ZnO}$. The $\mathrm{Cl}$ in $\mathrm{ChCl}$ interacts with the metal ions in the other three metal oxides by van der Waals forces. This can also be seen from the comparison of the density of the oxidation states of the four metals. Among the four metal oxides, the metal atom $\mathrm{Zn}$ is the most active, and the formed $\mathrm{Cl}-\mathrm{Zn}$ chemical bond exhibited strong bond energy. The chemical bond between $\mathrm{O}$ in MA and the metal atoms in the four metal oxides was weak because the $\mathrm{O}$ in the metal oxide forms strong chemical bonds with the metal atoms. By comparing the initial peak position and peak strength, it is found that the hydrogen bond strength formed by interaction with three metal oxides decreases in the order $\mathrm{Al}_{2} \mathrm{O}_{3}>\mathrm{ZnO}>\mathrm{Fe}_{2} \mathrm{O}_{3}$, and the interaction between $\mathrm{ChCl}-2 \mathrm{MA}$ and $\mathrm{CaO}$ was mainly based on van der Waals force. It can be concluded that the interaction between $\mathrm{ChCl}$ and $\mathrm{MA}$ and $\mathrm{ZnO}$ is dominated by chemical action and supplemented by physical forces. The interactions between $\mathrm{ChCl}-2 \mathrm{MA}$ and the other three metal oxides $\left(\mathrm{Fe}_{2} \mathrm{O}_{3}, \mathrm{Al}_{2} \mathrm{O}_{3}\right.$, and $\left.\mathrm{CaO}\right)$ are mainly physical. The analysis of the radial distribution function shows that the strength of the interaction between ChCl-2MA and the four metal oxides was consistent with the calculation results of the interaction energy. 


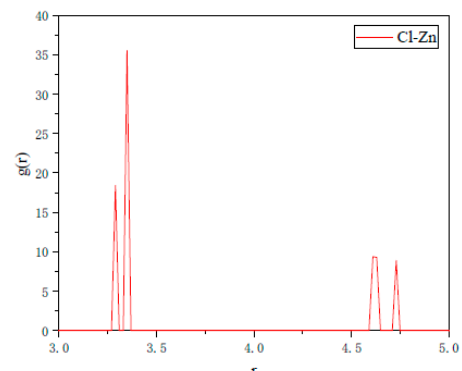

(a)

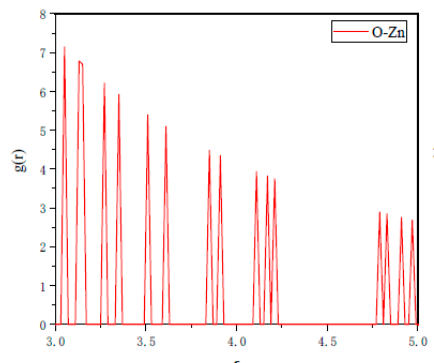

(b)

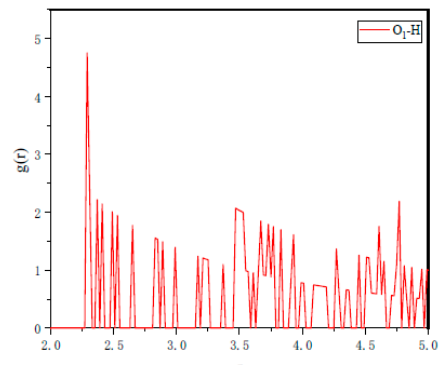

(c)

$\mathrm{ZnO}(001)$ surface and $\mathrm{ChCl}-2 \mathrm{MA}$ radial distribution (a): $\mathrm{Cl}-\mathrm{Zn}$ distance (b): $\mathrm{O}-\mathrm{Zn}$ distance (c): $\mathrm{O}_{1}-\mathrm{H}$ distance

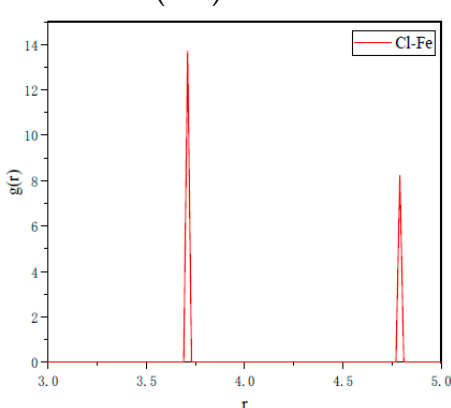

(d)

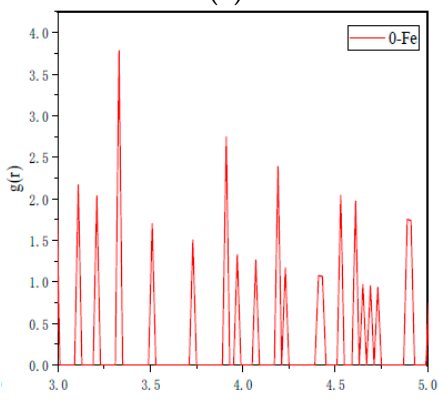

(e)

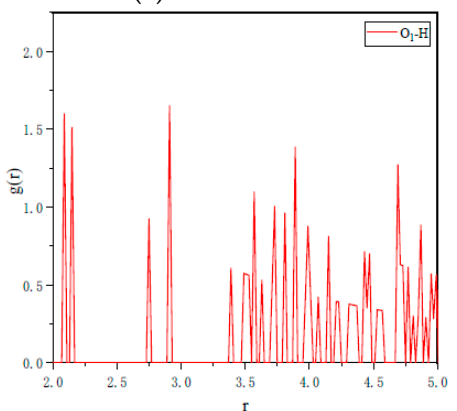

(f)

$\mathrm{Fe}_{2} \mathrm{O}_{3}(001)$ surface and $\mathrm{ChCl}-2 \mathrm{MA}$ radial distribution (d): $\mathrm{Cl}-\mathrm{Fe}$ distance (e): O-Fe distance (f): $\mathrm{O}_{1}-\mathrm{H}$ distance

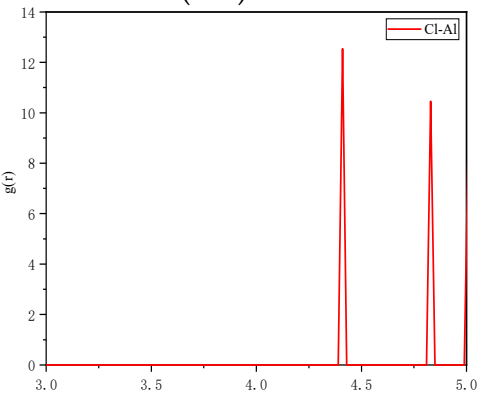

(g)

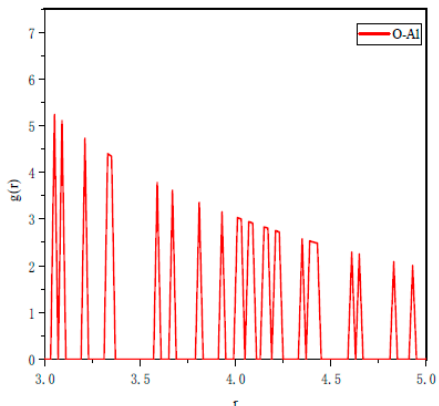

(h)

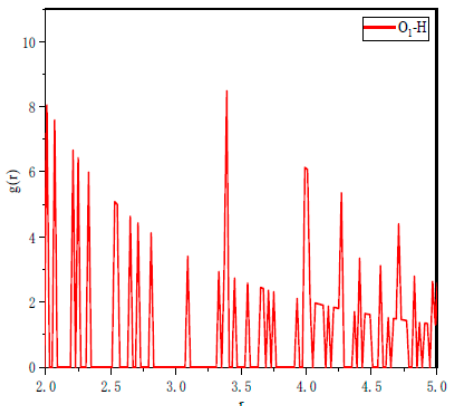

(i)

$\mathrm{Al}_{2} \mathrm{O}_{3}(001)$ surface and $\mathrm{ChCl}-2 \mathrm{MA}$ radial distribution (g): $\mathrm{Cl}-\mathrm{Al}$ distance (h): $\mathrm{O}-\mathrm{Al}$ distance (i): $\mathrm{O}_{1}-\mathrm{H}$ distance

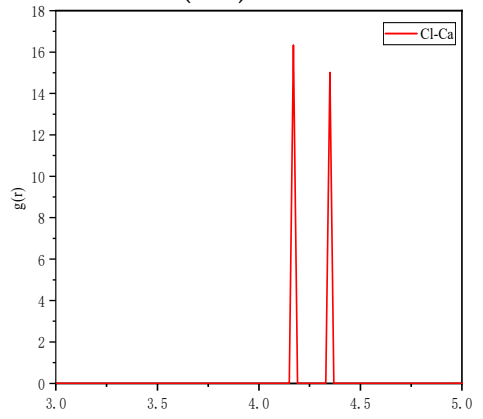

$(\mathbf{j})$

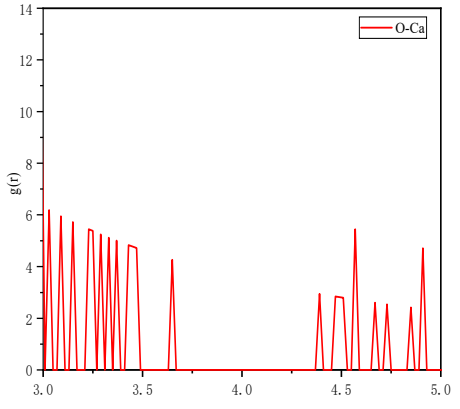

$(\mathbf{k})$

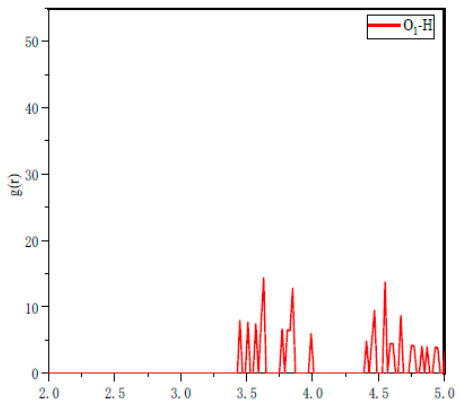

(1)

$\mathrm{CaO}(001)$ surface and $\mathrm{ChCl}-2 \mathrm{MA}$ radial distribution (j):Cl-Ca distance (k): O-Ca distance (1): $\mathrm{O}_{1}-\mathrm{H}$ distance

Figure 6. Radial distribution diagram of mineral adsorption model. $\mathrm{ZnO}$ (001) surface and ChCl-2MA radial distribution (a): $\mathrm{Cl}-\mathrm{Zn}$ distance $(\mathbf{b})$ : $\mathrm{O}-\mathrm{Zn}$ distance $(\mathbf{c})$ : $\mathrm{O}_{1}-\mathrm{H}$ distance. $\mathrm{Fe}_{2} \mathrm{O}_{3}$ (001) surface and $\mathrm{ChCl}-2 \mathrm{MA}$ radial distribution (d): $\mathrm{Cl}-\mathrm{Fe}$ distance (e): $\mathrm{O}-\mathrm{Fe}$ distance (f): $\mathrm{O}_{1}-\mathrm{H}$ distance. $\mathrm{Al}_{2} \mathrm{O}_{3}$ (001) surface and $\mathrm{ChCl}-2 \mathrm{MA}$ radial distribution (g): $\mathrm{Cl}-\mathrm{Al}$ distance (h): $\mathrm{O}-\mathrm{Al}$ distance $(\mathbf{i})$ : $\mathrm{O}_{1}-\mathrm{H}$ distance. $\mathrm{CaO}(001)$ surface and $\mathrm{ChCl}-2 \mathrm{MA}$ radial distribution (j): $\mathrm{Cl}-\mathrm{Ca}$ distance (k): $\mathrm{O}-\mathrm{Ca}$ distance (1): $\mathrm{O}_{1}-\mathrm{H}$ distance. 


\section{Model Verification and Analysis}

\subsection{Experimental Materials and Methods}

The particle size of $\mathrm{ZnO}, \mathrm{Fe}_{2} \mathrm{O}_{3}, \mathrm{Al}_{2} \mathrm{O}_{3}$, and $\mathrm{CaO}$ used in the experiment was $0.106-0.155 \mathrm{~mm}$, and the purity was greater than $99 \%$. Each leaching experiment was carried out with a total sample amount of $5.00 \mathrm{~g}$. $\mathrm{ChCl}$ and $\mathrm{MA}$ used in this study were analytically pure. First, $\mathrm{ChCl}$ and $\mathrm{MA}$ were mixed in a molar ratio of 1:2. The mixture was stirred in a beaker and placed in a vacuum drying oven at $80^{\circ} \mathrm{C}$ under $-0.05 \mathrm{MPa}$ for $12 \mathrm{~h}$ until the solids dissolved into a uniform transparent solution, which indicated that ChCl-2MA DES was formed. The leaching effects of $\mathrm{ChCl}-2 \mathrm{MA}$ were determined for the four metal oxides under various leaching temperatures, liquid-solid ratios, and leaching periods.

\subsection{Single Mineral Leaching Experiment}

The accuracy of the simulation results was verified using the ChCl-2MA leaching experiment for the four metal oxides. The leaching amounts of the four metal oxides for three different leaching parameters are displayed in Figure 7. The calculated results of the leaching were within an error of $2 \%$. Figure 7 a shows the leaching rate as a percentage at various temperatures and a fixed leaching time of $15 \mathrm{~min}$ and a liquid-to-solid ratio of 10:1. In Figure $7 \mathrm{~b}$, the leaching rate is plotted over the leaching time at a fixed leaching temperature of $70{ }^{\circ} \mathrm{C}$ and a liquid-to-solid ratio of 10:1. The liquid-to-solid ratio is varied in Figure $7 \mathrm{c}$ at a fixed leaching time of $15 \mathrm{~min}$ and a leaching temperature of $70^{\circ} \mathrm{C}$.

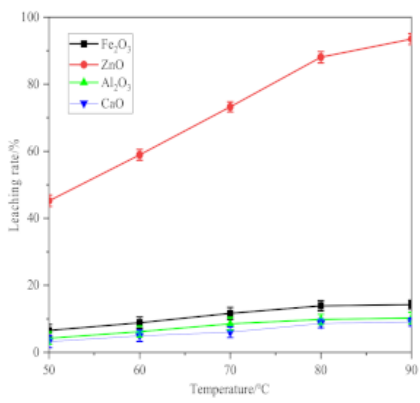

(a)

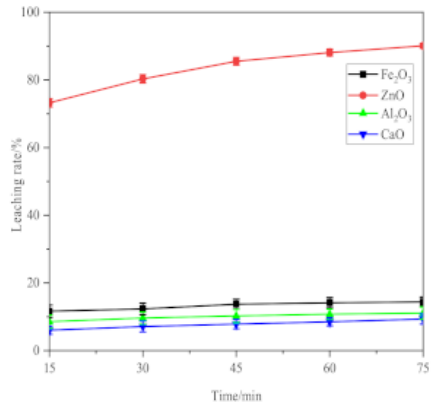

(b)

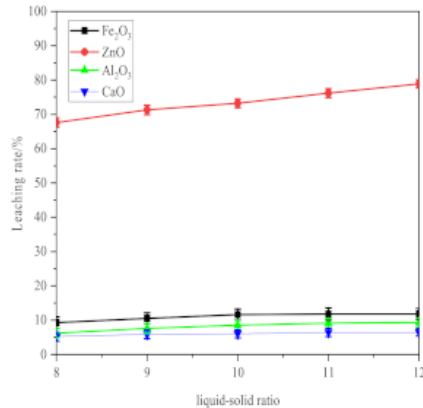

(c)

Figure 7. Leaching rates of metal oxides under different leaching conditions. (a): Leaching rates at different temperatures. (b): Leaching rates at different times. (c): Leaching rate of different liquid solid ratio.

According to Figure $7 \mathrm{a}$, the leaching of $\mathrm{ZnO}$ by $\mathrm{ChCl}-2 \mathrm{MA}$ varied greatly with different leaching temperatures. The leaching rate amounted to $45.21 \%$ at $50{ }^{\circ} \mathrm{C}$ and increased continuously to $93.48 \%$ at $90{ }^{\circ} \mathrm{C}$. The leaching for the other three metal oxides did not change much with the change in temperature and remained stable at about $10 \%$. At $90^{\circ} \mathrm{C}$, the highest leaching rate for the three metal oxides was observed with values of $14.23 \%$ for $\mathrm{Fe}_{2} \mathrm{O}_{3}, 10.23 \%$ for $\mathrm{Al}_{2} \mathrm{O}_{3}$, and $9.04 \%$ for $\mathrm{CaO}$. It can be seen from Figure $7 \mathrm{~b}$, c that, with the increase in leaching time and liquid-to-solid ratio, the leaching of $\mathrm{ZnO}$ by ChCl-2MA increased and, finally, reached a stable value, while the leaching of the other metal oxides showed little variation with the change in leaching time. The results show that, among various independent variables, the effect of leaching temperature was far stronger for $\mathrm{ZnO}$ than for the other three metal oxides.

\section{Conclusions}

(1) The optimal structural parameters of the four metal oxides were obtained by calculating their exchange-correlation energy functionals. Moreover, the complete-cleavage surfaces were calculated, and those with the lowest surface energy were found to be the (001) surfaces for all metal oxides. The optimized stable configuration of $\mathrm{ChCl}-2 \mathrm{MA}$ features multiple intermolecular hydrogen bonds with the chlorine atom as the center. 
(2) A comparative analysis of the cell and complete-cleavage surfaces density of the four metal oxides shows that the $\mathrm{ZnO}$ (001) surface near the Fermi level receives a higher contribution from the $\mathrm{Zn}-3 \mathrm{~d}$ orbital than the O-2p orbital. The $\mathrm{Fe}_{2} \mathrm{O}_{3}(001)$ surface near the Fermi level is contributed by Fe-3d and O-2p orbitals, and their activities are similar. The increase in the total density of states of the $\mathrm{Al}_{2} \mathrm{O}_{3}(001)$ surface is mainly due to the increase in the density of states of the O-2p orbital, indicating that the $\mathrm{O}-2 \mathrm{p}$ orbital is more likely to react with foreign substances. The peak density of states of the $\mathrm{CaO}$ (001) surface near the Fermi level is mainly contributed by the $\mathrm{O}-2 \mathrm{p}$ orbital, indicating that $\mathrm{O}$ is more likely to react with foreign substances in the complete-cleavage surface of $\mathrm{CaO}$.

(3) It can be seen from the energy change determined by molecular dynamics that $\mathrm{ChCl}$ $2 \mathrm{MA}$ is more likely to interact with the $\mathrm{ZnO}(001)$ surface. The variation in energy shows that $\mathrm{ChCl}-2 \mathrm{MA}$ is more inclined to interact with $\mathrm{ZnO}$ (001). The results also show that the interaction between $\mathrm{ZnO}$ and $\mathrm{ChCl}-2 \mathrm{MA}$ is the strongest, and the interaction of the metal oxides with $\mathrm{ChCl}-2 \mathrm{MA}$ decreases in the following order: $\mathrm{ZnO}>\mathrm{Fe}_{2} \mathrm{O}_{3}>\mathrm{Al}_{2} \mathrm{O}_{3}>\mathrm{CaO}$.

(4) Based on the analysis of the radial distribution function, it is inferred that the $\mathrm{Cl}$ in $\mathrm{ChCl}$ forms a chemical bond with $\mathrm{Cl}-\mathrm{Zn}$, whereas $\mathrm{Cl}$ interacts with $\mathrm{Fe}, \mathrm{Al}$, and $\mathrm{Ca}$ through van der Waals forces. The chemical bond of $\mathrm{Cl}$ is stronger than that formed by $\mathrm{Zn}$. The chemical bond between $\mathrm{O}$ in MA and metal atoms is weak. By comparing the initial peak position and the peak intensity, it is found that the strength of the hydrogen bond formed by the interaction between $\mathrm{ChCl}-2 \mathrm{MA}$ and the three metal oxides follows the descending order: $\mathrm{Al}_{2} \mathrm{O}_{3}>\mathrm{ZnO}>\mathrm{Fe}_{2} \mathrm{O}_{3}$. Moreover, the interaction between $\mathrm{ChCl}-2 \mathrm{MA}$ and $\mathrm{CaO}$ is mainly based on van der Waals forces.

(5) The leaching rate of the four metal oxides by $\mathrm{ChCl}-2 \mathrm{MA}$ was experimentally determined under different conditions for three leaching parameters. It is found that the leaching of $\mathrm{ZnO}$ by $\mathrm{ChCl}-2 \mathrm{MA}$ reaches more than $90 \%$, while the leaching for the other three metal oxides remains stable at about $10 \%$. These results verify the accuracy of the molecular simulation and also prove that $\mathrm{ChCl}-2 \mathrm{MA}$ is selective for $\mathrm{ZnO}$ in zinc-bearing dust sludge.

Author Contributions: J.Z. and C.Y. designed the experiments, C.Y. performed the experiments, J.D. analyzed the data, C.Y. and S.G. wrote the paper, and F.N. improved the paper. All authors have read and agreed to the published version of the manuscript.

Funding: This work is financially supported by the National Natural Science Foundation of China (51904106, 51874135), Natural Science Foundation of Hebei Province (E2021209015), and Tangshan Basic Innovation Team (19130207C).

Data Availability Statement: Data is available on request due to privacy restrictions. The data provided in this study can be obtained on request from the corresponding author. As the data needs further research, the data is currently not publicly available.

Conflicts of Interest: The authors declare no conflict of interest.

\section{References}

1. Yu, C.; Zhang, J.; Deng, J.; Chen, R.; Yu, X. The electrowinning of zinc from sodium hydroxide solutions. Hydrometallurgy 2014, $146,59-63$.

2. Zhou, H.; Li, J.; Cui, Z. Technology Study on Recovering Zinc from Steel Smelting Dust. Technology 2012, 10, 56-57.

3. Yu, X.; Xue, Q.; Wang, J. Comprehensive Utilization of Zinc-containing Dust in Iron and Steel Plants and Comparison of Related Treatment Processes. Ironmaking 2010, 29, 56-62.

4. Niu, F.; Ni, W.; Zhang, J. Current situation and development of comprehensive utilization of metallurgical dusts and slimes in China. Iron Steel 2016, 51, 1-10.

5. Mehmet, K.; Kürşad, O.; Mehmet, Ş.H. Optimization of selective leaching of Zn from electric arc furnace steelmaking dust using response surface methodology. Trans. Nonferrous Met. Soc. China 2015, 25, 2753-2762.

6. Xie, Z.; Guo, Y.; Chen, F. Research status and prospect of comprehensive utilization of zinc-bearing dust in iron and steel plants. Sinter. Pelletizing 2016, 41, 53-61. 
7. Chun, T.; Zhu, D. New Process of Pellets-Metallized Sintering Process (PMSP) to Treat Zinc-Bearing Dust from Iron and Steel Company. Metall. Mater. Trans. B 2015, 46,1-4. [CrossRef]

8. Wu, Z.; Huang, W.; Cui, K. Sustainable synthesis of metals-doped ZnO nanoparticles from zinc-bearing dust for photodegradation of phenol. J. Hazard. Mater. 2014, 278, 91-99. [CrossRef]

9. Sudhir, K.; Rocktotpal, K. Purification, characterization and biotechnological application of an alkaline $\beta$-keratinase pro-duced by Bacillus subtilis RM-01 in solid-state fermentation using chicken-feather as substrate. Biochem. Eng. J. 2009, 45, 218-225.

10. Turan, M.D.; Altundogan, H.S.; Tumen, F. Recovery of zinc and lead from zinc plant residue. Hydrometallurgy 2004, 75, 169-176. [CrossRef]

11. Abbott, A.P.; Boothby, D.; Capper, G. Deep eutectic solvents formed between choline chloride and carboxylic acids: Versatile alternatives to ionic liquids. J. Am. Chem. Soc. 2004, 126, 9142-9147. [CrossRef]

12. Wagle, D.V.; Zhao, H.B.; Baker, G.A. Deep eutectic solvents: Sustainable media for nanoscale and functional materials. Acc. Chem. Res. 2014, 47, 2299-2308. [CrossRef]

13. Zhang, Q.; Vigier, K.; Royer, S. Deep eutectic solvents syntheses properties and applications. Chem. Soc. Rev. 2012, 41, 7108. [CrossRef]

14. Lei, Z. Study on Treament of Zinc Dust with Deep Eutectic Solvents. Non-Ferr. Met. Smelt. 2017, 8, 5-8.

15. Zhang, Y.; Li, L.; Li, J. Dissolution behavior of zinc oxide in choline chloride oxalate hydrates deep eutectic solvents. J. Cent. South Univ. 2016, 47, 2591-2599.

16. Ashraf, B.; Volkmar, N. Recycling of cupola furnace dust: Extraction and electrodeposition of zinc in deep eutectic solvents. $J$. Alloy. Compd. 2019, 771, 424-432.

17. Zhu, X.; Xu, C.; Tang, Y. Selective recovery of zinc from zinc oxide dust using choline chloride based deep eutectic solvents. Trans. Nonferrous Met. Soc. China 2019, 29, 2222-2228. [CrossRef]

18. Peng, C.; Li, X.; Li, S. Adsorption of gold cyanide on quartz. Colloids Surf. A Physicochem. Eng. Asp. 2020, 590, 124514.

19. Peng, T.; Sheng, Q.; Jing, Q.; Zhang, L. First principle investigation of the surface states of tin dioxide (100). Mater. Sci. Semicond. Process. 2020, 113, 105020.

20. Jafarova, V.N.; Orudzhev, G.S. Structural and electronic properties of ZnO: A first-principles density-functional theory study within LDA(GGA) and LDA(GGA) + U methods. Solid State Commun. 2021, 325, 114166. [CrossRef]

21. Xiao, H.W.; Hai, J.P. Electron Properties of F, and N Doped Hematite: The Application for Photocatalysis. Adv. Mater. Res. 2012, $562,298-301$.

22. Kausar, H.; Norsakinah, M.; Zainal, A.A.; Ahmad, A.M. Electronic Properties of ZnO Nanoparticles Synthesized by Sol-gel Method: A LDA + U Calculation and Experimental Study. Procedia Chem. 2016, 19, 125-132.

23. Azam, S.; Irfan, M.; Abbas, Z.; Khan, S.A.; Khenata, R.; Muhammad, S.; Siddeeg, S.; Naqib, M.; Wang, S.H. Optoelectronic properties of Nd3+ doped CaTa2O6: Insights from the GGA + U calculations. Optik 2021, 225, 165270. [CrossRef]

24. Anwar, H.; Rana, C.; Javed, Y.; Mustafa, M.; Raza, A.; Hassan, A. Effect of ZnO on Photo catalytic Degradation of Rh B and Its Inhibition Activity for C. coli Bacteria. Russ. J. Appl. Chem. 2018, 91, 143-149. [CrossRef]

25. Chahal, S.; Kumar, A.; Kumar, P. Zn Doped $\alpha$-Fe2O3: An Efficient Material for UV Driven Photo catalysis and Electrical Conductivity. Crystals 2020, 10, 273.

26. Jie, X.; Qiao, L.; Fang, Y.; Yan, J.; Zhang, H.; Wu, X. Co-precipitation synthesis of alumina doped yttria stabilized zirconia. J. Alloy. Compd. 2018, 731, 1080-1088.

27. Maghsoudi, M.J.; Hadianfard, H.S. The influence of $\mathrm{Al}$ content and $\mathrm{CaO}-\mathrm{SiO}_{2}$ on the magnetic and structural properties of Al-substituted Ni ferrites. J. Alloy. Compd. 2009, 481, 539-542. [CrossRef]

28. Li, X.; Hai, Q.; Hao, Z.; Yuan, J. Molecular dynamics simulation of siderite-hematite-quartz flotation with sodium oleate. Appl. Surf. Sci. 2017, 419, 557-563. [CrossRef]

29. Gao, Z.; Sun, W.; Hu, Y. Mineral cleavage nature and surface energy: Anisotropic surface broken bonds consideration. Trans. Nonferrous Met. Soc. China 2014, 24, 2930-2937. [CrossRef]

30. Tan, X.; He, F.Y.; Xie, Y. Structural and Electronic Properties of $\mathrm{MnWO}_{4}(010)$ Surface Studied by First-principles calculation. Met. Mine 2015, 6, 52-58.

31. Agrawal, R.; Peng, B.E.; Espinosa, H.D. Experimental-computational investigation of ZnO nanowires strength and fracture. Nano Lett. 2009, 9, 4177-4183. [CrossRef]

32. Qing, J.; Zhao, Q.; Yang, Q.; Chen, Z.; Yin, Z.; Wu, Z. Behavior of silicon-containing minerals during Bayer digestion. Trans. Nonferrous Met. Soc. China 2010, 20, s1-s9.

33. Norio, W.; Naohiro, H.; Wei, W.; Tetsuo, H.; Miho, N.; Akiko, N. Electrical conduction and polarization of calcite single crystals. Phys. Chem. Miner. 2012, 39, 761-768.

34. Yang, Z.; Bai, X.; Zheng, W. Electronic properties of bare doped (Tio2)3 cluster-a density functional theory investigation. Mol. Phys. 2015, 32, 962-970.

35. Li, Y.; Chen, J.; Chen, Y.; Guo, J. Density functional theory study of influence of impurity on electronic properties and reactivity of pyrite. Trans. Nonferrous Met. Soc. China 2011, 21, 1887-1895. [CrossRef]

36. Chen, Y.; Chen, J. The first-principle study of the effect of lattice impurity on adsorption of CN on sphalerite surface. Miner. Eng. 2010, 23, 1887-1895. [CrossRef] 
37. Mahmoud, S.A.; Al-Hossainy, A.F.; Shaaban, E.R. Combined experimental and DFT-TDDFT computational, structural and study effect of inter-diffusion $\mathrm{Cu}$ into CdTe thick film by annealing for optoelectronics. J. Mol. Struct. 2021, 1238, 130411. [CrossRef]

38. Wang, J.; Ren, W.; Yan, S. Structural and dynamical properties of $\mathrm{H}_{2} \mathrm{O}$ molecules confined within albite-quartz system under cyclic thermal loading: Insights from molecular dynamic simulation. J. Mol. Struct. 2021, 1245, 131140. [CrossRef]

39. Marcus, P.; Grace, E.; Stephen, H.; Brendan, H.; Ian, H.; Stephen, T. Reactive Molecular Dynamics Study of the Thermal Decomposition of Phenolic Resins. J. Compos. Sci. 2019, 3, 32.

40. Fairushin, I.I.; Khrapak, S.A.; Mokshin, A.V. Direct evaluation of the physical characteristics of Yukawa fluids based on a simple approximation for the radial distribution function. Results Phys. 2020, 19, 103359. [CrossRef]

41. Hao, H.; Cao, Y.; Li, L.; Fan, G.; Liu, J. Dispersion and depression mechanism of sodium silicate on quartz: Combined molecular dynamics simulations and density functional theory calculations. Appl. Surf. Sci. 2021, 537, 147926. [CrossRef]

42. Hao, Z.; Wen, G.; Han, H. Effects of monohydric alcohols on the flotation of magnesite and dolomite by sodium oleate. J. Mol. Liq. 2018, 249, 1060-1067. 